https://doi.org/10.5719/aub-g/69.1/3

\title{
THE RELATION BETWEEN FLUVIAL GEOMORPHIC FRAME AND ROMAN ARCHAEOLOGICAL SITES DISTRIBUTION IN THE TIMIȘ VALLEY BETWEEN CARANSEBEȘ AND LUGOJ
}

\author{
SORIN HADRIAN PETRESCU1, MARIA HOSU²
}

\begin{abstract}
The main advantage of using interdisciplinary research methods is that new approaches and insights regarding the interractions between past communities and landforms may be performed. The main aim of this paper is to assess by using high quality archaeological record data and high resolution LIDAR support the connection between Roman archaeological sites and fluvial geomorphic frame. The study area is represented by Timiș Valley between Caransebeș and Lugoj, in the Southwest of Romania, part of the former Roman province of Moesia Superior. Thus, the paper is divided into two main sections. The first one is represented by the mapping of the fluvial landforms. High resolution LIDAR support, aerial photography and topographical maps were used in geomorphic mapping. This first step focused on fluvial landforms (valley margin, terraces, meadows, alluvial fans, transition areas etc.). Secondly, a total number of 37 Roman archaeological sites were mapped and overlapped on the fluvial landforms. Proximity and spatial analysis operations were performed. We believe that the results highlights an unexpectedly significant connection between the Roman sites and the fluvial geomorphic frame. These results have also strenghtened our innitial presumptions regarding the importance of relief in Antiquity in the Southwest of Romania.

Keywords: Roman sites, Timiş Valley, fluvial landforms, geomorphic mapping, spatial analysis.
\end{abstract}

\section{Introduction}

Identifying the relationship between the geomorphic landscape and Roman arachaeological sites spatial distribution may lead us into

1 Faculty of Geography, Babeș-Bolyai University, E-mail: sorinp63@yahoo.com

2 Faculty of Geography, Babeș-Bolyai University, E-mail: maria.hosu@ubbcluj.ro 
finding new insights regarding the role of relief in the spatial organization of Roman Antiquity. It may also allow researchers to initiate new theories and also new approaches regarding the humanenvironment relation by using interdisciplinary research methods from geomorphology and archaeology. The geomorphological diversity and complexity of the fluvial landforms and some of their main characteristics (in terms of elevation, fragmentation or symmetric/asymmetrical extent) facilitates some interpretation opportunities (Grecu, 2018).

For Timiș Valley, the second half of the last century was considered to be the most active in terms of archaeological systematic research regarding the Roman period. Several studies have been carried out in the area. The first study was carried out by (Moga, 1970) and refers to the roman site of Tibiscum. Since then, many other studies and systematical research have been done within Timiș Valley among which more important are those of (Benea, 2003), (Ardeț, 2004), (Petrescu, 2017) and (Benea, 2018). However, the connection between fluvial geomorphic frame and all the Roman archaeological sites discovered until now have not been studied yet.

\section{Study area and general context}

The study was conducted in the Timiș Valley, which is located in the Southwestern Romania, at the intersection between the Southern Carpathians and the Western Carpathians, on the coordinates $45^{\circ} 23^{\prime} 55.28^{\prime \prime} \mathrm{N}, 22^{\circ} 13^{\prime} 20.28^{\prime \prime} \mathrm{E}$ and $45^{\circ} 44^{\prime} 8.35^{\prime \prime} \mathrm{N}, 21^{\circ} 51^{\prime} 12.47^{\prime \prime} \mathrm{E}$. The area is part of Timiș-Cerna tectonic corridor and is located on a horst-graben blocks structure. The environment was submerged by Paratethys sea water until late Sarmatian Stage ( Upper Middle Miocene) (Linc, 2002). In the middle sector of the Timiș basin, the morphohydrographic character of the river changes when flowing through the more friable Miocene sedimentary rocks. The influence of petrography and climatic factors led to the formation of a larger corridor between Caransebeș and Lugoj (Grecu, 2010). The area is extended over Timiș Depression, Bistra Corridor, Muntele Mic Mountains and Nemanu Massiv in the South, Poiana and Buziaș Hills in the West, Sinersig Plain in the central part, 
Timișana Plain in the North and Lugoj Hills and Poiana Ruscă Mountains in the East (Fig.1). Nowdays the area is dominated by active hillslope and fluvial modelling processes. From the total area of 1714 $\mathrm{km}^{2}, 695.3 \mathrm{~km}^{2}$ are represented by the fluvial goemorphic complex area, which is bordered on the upper limit by the valley margin (Wheaton et al., 2015). The terraces system is widely developed, with a total number of six terrace steps. The terraces distribution is asymmetrical. The Qt4 and Qt5 terraces are the most extended. The Timiș River floodplain, which is bordered by the valley bottom margin on its external part, is well developed. It is connected with other tributary floodplains or connected with the lower terraces through steep slopes or inactive alluvial fans. The elevation ranges from under $200 \mathrm{~m}$. in the internal Timiş floodplain to more than $1200 \mathrm{~m}$. on the main mountainous interfluves of the valley (Grigore, 1981).

The Roman period sites are highly developed in the study area (Luca, 2006). Due to the morphological connectivity between Moesia Superior and Moesia Inferior, the Timiș valley had a key role in the spatial organization of the roman province. One major advantage of this sector of valley is the location at the intersection of two major Roman imperial roads. The first one from east to west was connecting Sarmizegetusa Ulpia Traiana - Tibiscum-Berzobis. The second one from south to north was connecting Dierna- Tibiscum-Sarmizegetusa Ulpia Traiana (Fodorean et al., 2013). Because of its ancient importance for the Empire the area has been the research subject for several archaeological studies. Most of them are focused on the daily life of the Roman settlements (Benea, 2003), (Ardeț, 2004), and on the reconstruction of the extension of these archaeological sites (Hegyi, 2018). The intense archaeological research revealed a total number of 26 roman settlements and 11 other types of findings ( necropolis, thesaurus and other). In contrast to Prehistory, in the Roman period human communities did not rely only on environmental factors and heuristical adaptability decisions (Hussain et. al, 2015). Despite prehistoric comunities, the romans still took into consideration the landform main characteristics and geomorphometry when organizing their settlements or military constructions in relation with the spatial organisation of the conquered territories (Ardeț, 2004). 


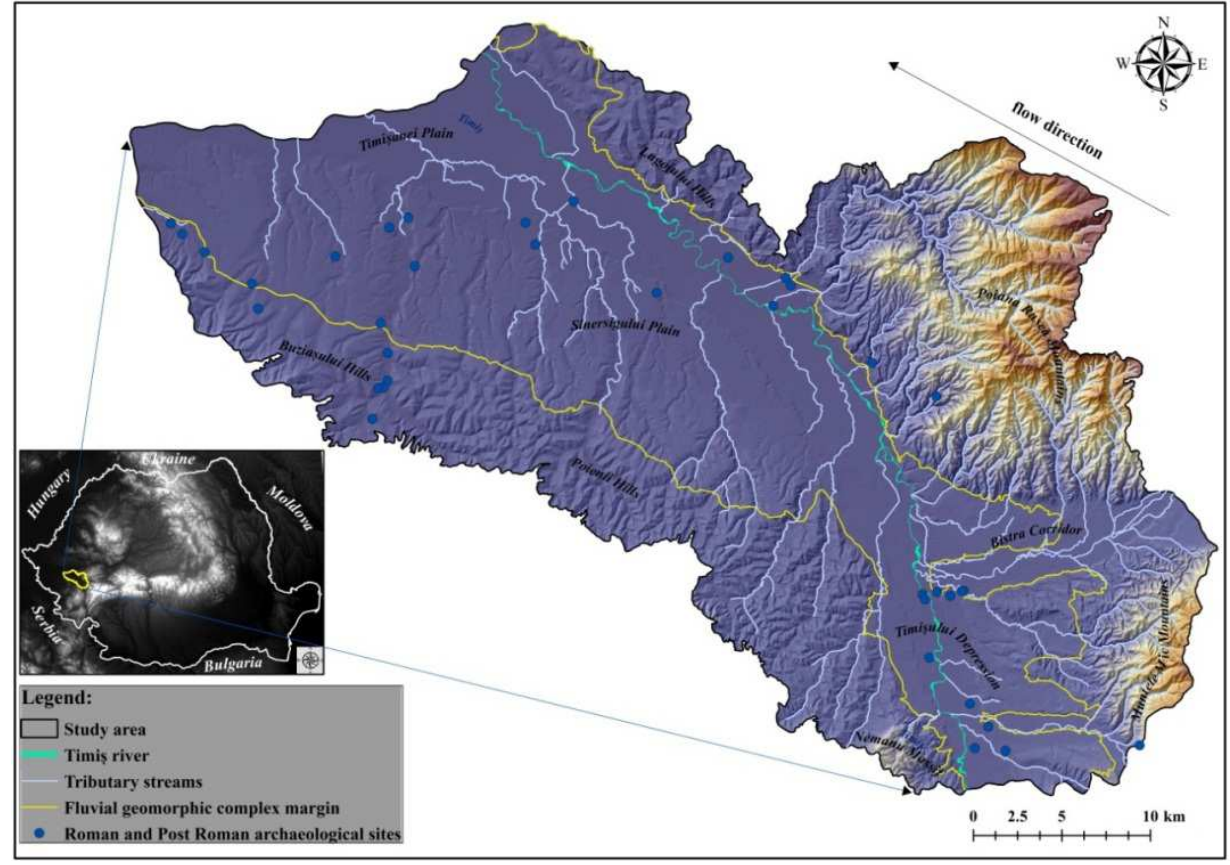

Fig. 1. The location of the study area

\section{Materials and methods}

Several cartographic and other graphic supports were used for the research. For both geomorphic mapping and archaeological purposes, topographic maps (1: 25 000), orthophotographs and LIDAR data were used. Regarding the geomorphic frame of the area, the mapping process started with the mapping of the valley margin, which, according to (Wheaton et al., 2015) is represented by the external limit of the fluvial terraces system. This margin also represents the limit of the fluvial geomorphic system of Timiș River.

A prioritary aspect regarding the Roman and post Roman archaeological sites mapping is to locate as precise as possible the physical structures of buildings, walls and other anthropogenic constructions. Thus, primary official data were collected from the Romanian National Archaeological Record (www.cimec.ro) and from the National Heritage 
THE RELATION BETWEEN FLUVIAL GEOMORPHIC FRAME AND ROMAN ARCHAEOLOGICAL

SITES DISTRIBUTION IN THE TIMIȘ VALLEY BETWEEN CARANSEBEȘ AND LUGOJ

Institute of The Ministry of Culture survey (www.patrimoniu.ro). In order to spatially identify the prehistoric settlements, official archaeological sheets of the sites have been consulted. Very often, the description within the identification sheets were not clearly described. Several LIDAR mapping and direct field localization were necessary (using hand held GPS, based on the existing references). Expert archaeologists were also consulted. In many cases the data about site landform location had several interpretation errors so we used LIDAR scans to map the sites and the surrounding landforms. The Roman archaeological sites were mapped as point feature and have been structured by adding 5 new fields (Di Leo et al., 2017) in their attribute table (type, category, national archaeological record code (NAR), chronology and the type of site stratigraphy) (Table. 1). 
The structure of the archaeological database

\begin{tabular}{|c|c|c|c|c|c|}
\hline Site & Category & Type & NAR code & Chronology & Stratigraphy \\
\hline 1 & habitation & settlement, necropolis & 51029.03 & Roman & complex site \\
\hline 2 & habitation & settlement & 51029.4 & Roman & complex site \\
\hline 3 & habitation & villa rustica & 51029.18 & Roman & complex site \\
\hline 4 & funeral & tumulus & 51029.17 & Roman & artifacts \\
\hline 5 & habitation & settlement & no data & Roman & artifacts \\
\hline 6 & habitation & settlement & 156650.01 & artifacts \\
\hline 7 & habitation & settlement & 156650.04 & Roman (II-IV century) & complex site \\
\hline 8 & habitation & settlement (vicus) & 51038.01 & Roman & complex site \\
\hline 9 & habitation & thermae & 51038.01 & Roman & complex site \\
\hline 10 & funeral & necropolis & 53407.02 & Roman & complex site \\
\hline 11 & habitation & urban settlement & 53407.01 & artifacts \\
\hline 12 & sacred & temple ( fanum) & no data & Roman & complex site \\
\hline 13 & funeral & necropolis & no data & Roman (II-IV century) & artifacts \\
\hline 14 & habitation & settlement & 159268.01 & Roman & artifacts \\
\hline 15 & habitation & settlement & 159268.02 & Roman & artifacts \\
\hline 16 & habitation & settlement & 159320.08 & Roman & artifacts \\
\hline 17 & habitation & settlement & 159320.09 & artifacts \\
\hline 18 & monetary & roman coins & no data & Roman & artifacts \\
\hline 19 & monetary & roman coins & no data & Roman (IV century) & artifacts \\
\hline 20 & monetary & roman coins & no data & Roman (III century, Probus) & artifacts \\
\hline 21 & exploitation & iron mine & 53782.04 & Roman & artifacts \\
\hline 22 & thesaurus & monetary thesaurus & no data & Roman (Republican) & Ran \\
\hline 23 & habitation & settlement & 54421.02 & & Ran \\
\hline
\end{tabular}




\begin{tabular}{|l|l|c|c|c|c|}
\hline 24 & habitation & settlement & 156543.01 & Roman (III century A.D.) & artifacts \\
\hline 25 & habitation & settlement & 156570.05 & Roman & artifacts \\
\hline 26 & thesaurus & monetary thesaurus & No data & Roman & artifacts \\
\hline 27 & habitation & settlement & 156632.01 & Roman (III-IV A.D.) & artifacts \\
\hline 28 & habitation & settlement & 156632.02 & Roman (III-IV A.D.) & artifacts \\
\hline 29 & habitation & settlement & 156632.03 & Roman & artifacts \\
\hline 30 & habitation & settlement & 156632.04 & Roman (III-IV A.D.) & artifacts \\
\hline 31 & habitation & settlement & 156632.05 & Roman (III-IV century) & artifacts \\
\hline 32 & habitation & settlement & 157040.03 & Roman & artifacts \\
\hline 33 & habitation & settlement & 157040.04 & Roman & complex site \\
\hline 34 & habitation & open settlement & 155412.02 & artifacts \\
\hline 35 & habitation & open settlement & 155412.03 & Post Roman (III-IV century) & artifacts \\
\hline 36 & habitation & open settlement & 155412.06 & Post Roman (III-IV century) & Roman \\
\hline 37 & habitation & settlement & 155369.06 & & complex site \\
\hline
\end{tabular}

(Data Source: Romanian National Archaeological Record www.cimec.ro) 
A large variety of cartographic methods, proximity analysis and spatial analysis tools (point density, euclidean distance, near) were used in order to identify and analyze the connection between sites distribution and the geomorphic frame of the Timiș Valley from a geomorphic perspective. Three main factors were took into consideration: elevation, landform and water resources proximity. The main reason why these particular factors were chosen is because excepting the political and economical premises of habitation of Antiquity, the landform favourability, elevation and water resources represent vital aspects of a prosperous habitation environment.

\section{Results}

Through GIS modelling methods and fieldwork mapping, interesting aspects regarding the connection between Roman sites distribution and the geomorphic frame have been revealed. The fluvial geomorphic system within the valley limit was systematically mapped. A total number of 6 terraces have been identified in the area, from the lower terrace Qt1 $(10 \mathrm{~m})$ to the higher terrace Qt6 $(120 \mathrm{~m})$. Also the Timiş river meadow was mapped as well as tributary meadows which represent recently deposited alluvionary materials. The aluvial fans make the transition from the higher hillslope areas and the main meadow deposits. An interesting aspect with a high role on sites distribution is the asimetry of the terrace system and also of the alluvial fans from the South to North. The terrace system is very eroded due to secondary erosional processes after the terraces have been cut off from the former floodplain. There is a high degree of fragmentation specific to all terrace steps (caused by gully erosion, torrentiality, tributary streams erosion).

From a geomorphic point of view, the distribution of the roman sites within Timiș valley depends on 3 factors: elevation, landforms and river proximity. The elevation of the study area ranges from a minimum elevation of $101 \mathrm{~m}$ in the Northern part to $1304 \mathrm{~m}$ in the Southeastern part, in the proximity of Muntele Mic Mountains. All of the 37 sites are located within the $<101-400 \mathrm{~m}$ elevation class, which overlaps mostly gravel, sand and red clay deposits. One first reason may refer to the 
necessity of proximity to the imperial roads network and the second one to the proximity to major rivers such as Timiș River and the flatter area of the terrace treads. (Fig. 2)

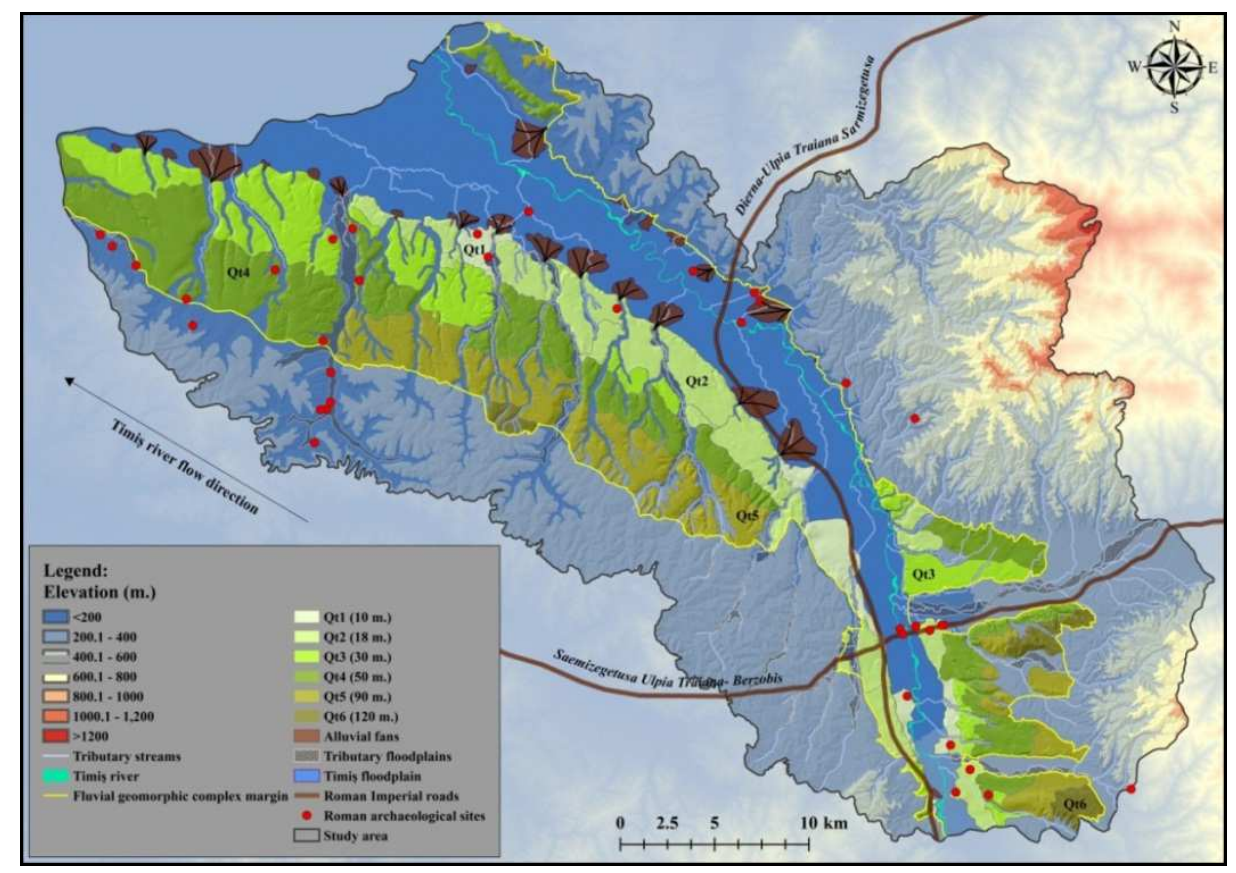

Fig. 2. The geomorphic map of Timiș valley and the distribution of roman sites

The asymmetrical spatial distribution of the fluvial terraces had a key role in the distribution of the sites. From the most Southern part of the area until the confluence point with Bistra river, the majority of the sites are located on the right side of the river because the terrace areas are poorly developed on the left side. In this part the transtition between the floodplain and the valley bottom margin (Wheaton et al., 2015) is represented by the lower terraces (Qt1 - $10 \mathrm{~m}$ and $\mathrm{Qt2}-18 \mathrm{~m}$ ). The confluence point with Bistra tributary also represents a strategical crossroads point of two main imperial roads. The first one from West to East Sarmizegetusa Ulpia Traiana - Tibiscum-Berzobis and the second one, from South to North-East, Dierna-Tibiscum-Sarmizegetusa Ulpia Traiana. In this area, there is a higher density of roman sites and also the location of the 
ancient city of Tibiscum. From this area to the North the distribution of the sites is changing also because of the asymmetrical extension of the fluvial terraces. On the right side of the tiver the transition from the lower meadow areas to the hillslopes is made by steep slopes and parasiting alluvial fans. There is only one site which is located on an alluvial fan toe. The rest of the existing sites in this area are located on hillslopes. The higher extension of terraces and tributary floodplains in the Western and Nortwestern part of the study area with low ocupation restrictivity led to a high density of Roman sites which are located mostly on terrace treads and tributary meadows. The main disadvantage of these sites is the higher isolation degree regarding the connection with the main imperial roads.

The landform sites spatial distribution diagram (Fig. 3) shows a precise state regarding the number of Roman sites on each landform. The majority of the sites are located on terrace treads with about $45.9 \%$ of the total number of 37 sites. Most of the sites are located on the Qt2 and Qt4 terraces. Fluvial terraces provided flat surfaces and close water resources which made them optimal for habitation. Close to terraces are the meadow areas which sum both Timiș river and tributary meadows. The sites which are located in these areas represent about $32.6 \%$ of all sites. Meadow areas have two main advantages. Firstly the Timis, meadow also involves a proximity to the river (transportation, trade, agricultural purposes). Secondly both main and tributary meadows represented easy access, closer water resources as well as that the local particular topography provided a mild topoclimate. 


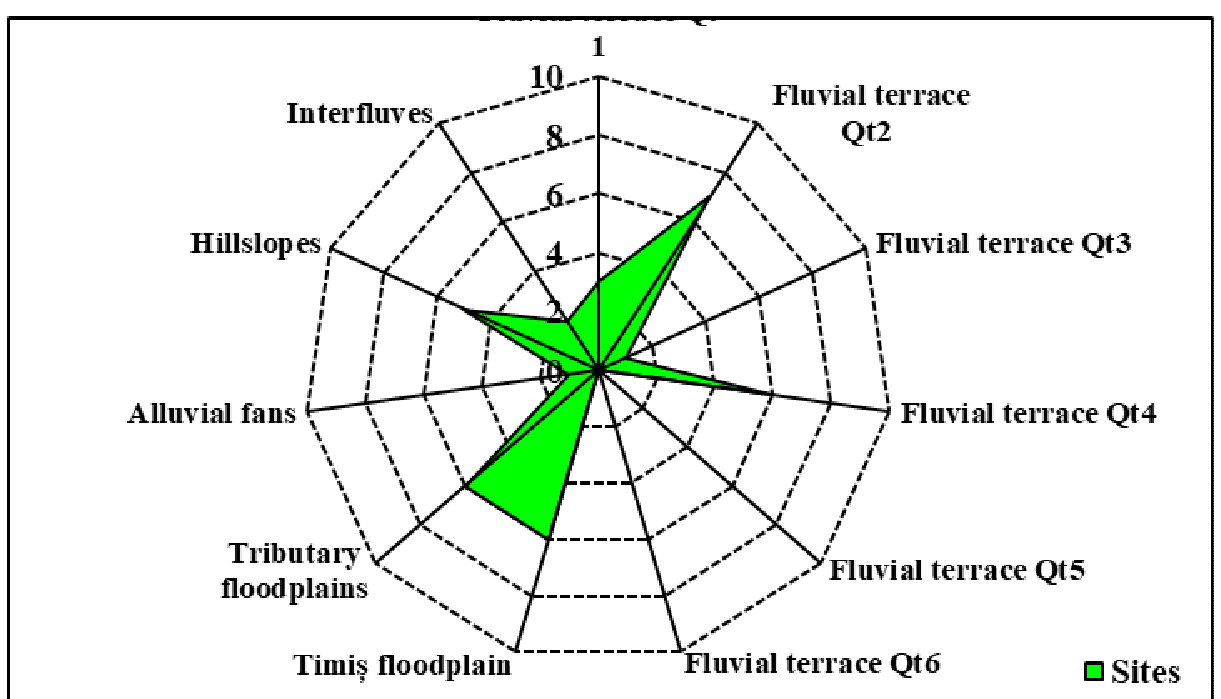

Fig. 3. Diagram showing the landform site distribution within the study area

More detailed geomorphic mapping revealed quite intriguing aspects of sites distribution. As in the case of the ancient site of Tibiscum, a geomorphic mapping using LIDAR support helped us to highlight some aspects regarding the relation between indirect floodrisk perception and protection and site location (Fig. 4). The site of Tibiscum is located in the Southern part of the Timiș valley, near the confluence point between Timiș and Bistra at an elevation of $185 \mathrm{~m}$.. The location of the site is on the left side of the river, within Timiş meadow. An elevation difference of about 4 meters protected the site of Tibiscum from major flood events. Also the river itself may be considered as a natural barrier with a high protection role on the east. Historic planiform morphodynamics of Timis river affected a significant area of the Roman city. The position of the site was chosen upstream from the confluence point with Bistra river, which is the Timiș largest tributary. This choice might have been taken in order to avoid possible flood events downstream the confluence point. 




Fig. 4. Detailed map of Tibiscum archaeological site and cross section in relation with meadow morphology

The general geomorphic structure of the Timiș River Valley has shaped the streams network within the study area. The alternating horst and graben structures led to the fragmentation of drainage network and also to a steeper connection between the hillslopes and the valley bottom. The alternation of mountain, hills and lower plain areas have a high impact on streams spatial distribution. In the southeastern and western part which overlap on mountainous areas and high elevation slopes a higher streams density can be observed while in the lower hills and plain area from the west and northwest, the stream density is low. Except Bistra and Sebeș rivers, there is a high occurency of Timiș river main tributaries in the western part of the study area. In this part the extended terraces system have led to a higher fragmentation degree. The springs alignment is often located at the upper contact between the hillslopes and the upper terrace cycle (Qt6 and Qt5). 
THE RELATION BETWEEN FLUVIAL GEOMORPHIC FRAME AND ROMAN ARCHAEOLOGICAL SITES DISTRIBUTION IN THE TIMIȘ VALLEY BETWEEN CARANSEBEȘ AND LUGOJ

The investigation of site distribution corelated with the stream network also can reveal key aspects regarding the perception of the geomorphic environment in Antiquity. The results regarding the importance of streams in site distribution highlighted that $89.1 \%$ of the total number of 37 sites are located in the proximity of a stream (mostly permanent streams). The value of the maximum proximity to the closest stream was considered to be under $500 \mathrm{~m}$ length. Only $10.8 \%$ of the sites are located between 500.1-1000 m length which indicate a settlements tendency of being close to a stream. The maximum stream proximity is represented on the map (Fig. 5) with dark blue. It is necessary to be mentioned that there is a link between terrace treads fragmentation due to stream erosion, stream proximity and the location of the sites.



Fig. 5. The relation between archaeological sites and stream network in the Timiş Valley

\section{Conclusions}

Geomorphic mapping, archaeological data analysis along with proximity analysis carried out in the study area are able to unravel the 
Roman settlements dynamics within Timiș Valley. Furthermore, the Roman sites distribution in relation with landforms create a different perspective regarding the human-environment interaction through time.

There is an interesting chain relation between the geomorphic structures, elevation, landforms, stream network and Roman archaeological sites. The alternant geomorphic structure of horst and graben influence the elevation and landform general configuration and its asymmetrical extent. But vital implications are regarding the influence on stream network type. Unexpectedly, the majority of the Roman sites are located on lower elevation areas by reasons that we previously attempted to explain. On landforms, the sites tend to appear on productive meadow areas and lower terrace treads. A high occurency on the contact line between valley margin and valley bottom margin and close to imperial roads ( also the margin of Timiș river meadow) has been noticed.

We put that aspect on the fact that Moesia Province was a border province of the Empire so all settlements had to located closer to roads, on flat areas with high visibility. The most intriguous relation we consider to be between the sites and the stream network. All the Roman sites from the study area are located within a $500 \mathrm{~m}$. distance buffer to the closest water source.

For future perspectives, more work needs to be done such as more detailed information regarding the size of each site and the relation between the sites and other geomorphic parameters.

\section{Acknowledgements}

The authors would like to express their special appreciation to the Romanian Water Administration with its regional subsidiary institution of Banat Water Administration for providing us LIDAR DTM for Timiș river valley and to the Museum of the Highland Banat from Reșița and the County Museum of Etnography and Border Regiment, Caransebeș for archaeological information. 
THE RELATION BETWEEN FLUVIAL GEOMORPHIC FRAME AND ROMAN ARCHAEOLOGICAL

\section{REFERENCES}

Arba, Andreea, R., 2012, The Periods with Pluviometric Surplus from the Timiș Hydrographical Basin (1965-2009), in Forum Geografic. Studii și cercetări de geografie și protecția mediului, Volume XI, Issue 2, pp. 209-213.

Ardeț, A., Ardeț, Lucia, C., Tibiscum-Așezările romane, 2004, Ed. Nereamia Napocae, Cluj-Napoca, Romania.

Benea, Doina, 2003, Istoria așezărilor de tip vici militares din Dacia Romană, Editura Excelsior Art, Timşoara.

Benea, Doina, 2018, Castrul roman de la Tibiscum, Editura Artpress, Timișoara.

Benea, Doina, Cronica Cercetărilor Arheologice din România. Campania 2000, CIMEC-Institul de Memorie Culturală, Bucureşti, 2001, 274-275.

Burghelea, Bianca, Bănăduc, D., \& Curtean-Bănăduc, Angela, 2013, The Timiș river basin (Banat, Romania) natural and anthropogenic elements. A study case - Management challenges, in Transylvanian Review of Systematical and Ecological Research 15, special issue, pp. 173-206.

Costea, Mărioara, 2013, Some Geomorphologic Aspects along the Timiş River in the Romanian Sector, in Transylvanian Review of Systematical and Ecological Research 15, special issue, pp. 23-32.

Di Leo, Paola \& Bavusi, Massimo \& Corrado, Giuseppe \& Danese, Maria \& Giammatteo, Tonia \& Gioia, Dario \& Schiattarella, Marcello, (2017), Ancient settlement dynamics and predictive archaeological models for the Metapontum coastal area in Basilicata, southern Italy: from geomorphological survey to spatial analysis. Journal of Coastal Conservation. 10.1007/s11852-017-0548-y.

Fodorean, F., Fodorean, I., Moldovan, C., Recreatind the landscape of the former Roman Dacia using modern $19^{\text {th }}$ century cartography, digital data and GIS, in e-Perimetron, vol.8,No.1, 2013, pp. 37-35.

Grecu, F., 2010, Geografia Câmpiilor României, Editura Universităţii din Bucureşti, pp. 260.

Grecu, F., 2018, Geomorfologie dinamică pluvio fluvială. Teorie şi aplicații, Editura Universitară, Bucureşti, DOI: 10.5682/9786062807276, pp. 475.

Hegyi, A., 2018, Modalități de aplicare a metodelor specifice geoștiințelor în cercetări arheologice din sud-vestul României, PhD Thesis, Timișoara, Romania.

Hussain, S.T., Floss, H., 2015 Streams as Entanglement of Nature and Culture: European Upper Paleolithic River Systems and Their Role as Features of Spatial Organization, in Journal of Archaeological Method and Theory, (2016) 23:1162-1218.

Linc, Ribana, 2002, Culoarul Timiș-Cerna, Editura Universității din Oradea, Oradea.

Lines, H[enry]. H[arris]., Roman Castrametation [I], În: The Antiquary, Vol XXI, January-June 1890, pp. 6-12, on-line http://archive.org/details/antiquary22appegoog (28.12.2012).

Luca, S.A., Suciu, C., Purece, S.I., 2006, Archaeological Discoveries from Romanian Banat. Repertoire, Ed. Altip, Alba-Iulia.

Moga, M., Garnizoana romană de la Tibiscum, 1970, in Acta Musei Napocensis, vol. 7, pp. 135-149.

Niknami, A.K., Irandoust, H., Tahmasebi, A., Environmental and Cultural Factors Influencing Parthian Archaeological Site Distribution in the Sarfirouzabad Plain of Kermanshah, 
Northwest of Iran, in International Journal of Geosciences, 4, 69-77, 2013, http://dx.doi.org/10.4236/ijg.2013.41008

Petrescu, S.M., 2017, Monografia Caransebeşului/A monograph of Caransebeş, Preistoria/ Prehistory (approx.40.000-650 B.C), Editura Dalami, Caransebeş.

Petrescu, S.H., Gligor, V., 2016, Vulnerability assessment of the geomorphological risk processes and risk management in the context of urban development. The case of Caransebeș municipality, in Geographia Napocensis, Anul X, nr. 2, pp. 65-72.

Petrescu, S.H., Gligor, V., 2017, Lateral adjustments of Timiș river channel between 19652015, in Geographia Napocensis, Anul XI, nr. 2, pp. 49-58.

Petrescu-Burloiu, I., 1949, Considerațiuni fizico-geografice asupra regiunii și orașului Caransebeș, Imprimeriile Penitenciarului “Văcărești”, București.

Petrovszky, R., Contribuții la repertoriul arheologic al localităților județului Caraş-Severin din paleolitic până în secolul al V-lea î.e.n. (partea II), Banatica, 3, 1975, 365, 367.

Petru et al., Fortificații romane în Banat (I). Cornuțel, BCSS, 7, 2001, 113-116.

Posea, G., 1992, Câmpiile României: Câmpia Banato-Crișană. Partea 4: Subregiunea Câmpia Banatului, București.

Urdea, P., Cîntar, A., 2014, Cadrul geografic și elementele morfologice ale peisajului așezării militare și civile din rezervația arheologică Tibiscum, in ArheoVest, Nr. II: [Simpozion ArheoVest, Ediția a II-a:] In Honorem Gheorghe Lazarovici, Interdisciplinaritate în Arheologie, Timișoara, 6 decembrie 2014, Vol. 1: Arheologie, Vol. 2: Metode Interdisciplinare, Asociația "ArheoVest" Timișoara, JATEPress Kiadó, Szeged.

Wheaton, J.M., Fryirs, A. Kirstie, Brierley, G., Bangen, Sara G., Bouwes, N., O’Brien, G., 2015, Geomorphic mapping and taxonomy of fluvial landforms, in Geomorphology 248 (2015) 273-295.

www.cimec.ro

www.patrimoniu.ro 